\title{
ANALISIS MORFOMETRIK DAN INDEKS KONDISI KERANG BATIK (Paphia undulate.) DI PERAIRAN CIREBON
}

\section{MORFOMETRIC ANALYSIS AND CONDITION INDEX OF SHELLFISH Paphia undulate IN THE CIREBON WATER}

\author{
Devi Nurkhasanah, Elinah, Eulis Henda Nugraha \\ Program Studi Teknik Sistem Perkapalan, \\ Fakultas Teknologi Kelautan Perikanan, Universitas Nahdlatul Ulama, Cirebon \\ Korespondensi: 123devinurkhasanah@gmail.com
}

\begin{abstract}
The Cirebon Regency water is ones of the shellfish production area which have high economic value and are widely consumed by the community. The purpose of this research is to analyze the growth and condition index of batik shells in Cirebon waters. This research used quantitative descriptive analysis. This research was conducted in FebruariApril 2020 in the waters of Cirebon. Location of Cirebon waters are divided into three stations that are considered to represent each region, i.e. coastal Mundu Village, coastal Bondet Village, and coastal Playangan Village. The analytical method used was morphometric analysis and condition index of the shellfish. The results showed that the growth of batik clams was negative allometric and the condition index of mussels was small and medium.
\end{abstract}

Keywords: condition index, morphometric, shellfish paphia undulate

\begin{abstract}
ABSTRAK
Perairan Kabupaten Cirebon merupakan salah satu wilayah yang banyak menghasilkan kekerangan, yang bernilai ekonomis tinggi dan banyak dikonsumsi oleh masyarakat. Tujuan dari penelitian ini adalah untuk menganalisis pertumbuhan dan indeks kondisi kerang batik yang ada di Perairan Cirebon. Metode penelitian ini dilakukan secara deskriptif, melalui pengumpulan data dengan menggunakan metode survei. Penelitian ini dilakukan pada bulan Februari-April 2020 di perairan Cirebon. Lokasi diperairan Cirebon dibagi menjadi tiga yang dianggap mewakili masing-masing wilayah, perairan Mundu, perairan Bondet, dan perairan Playangan. Metode analisis yang digunakan adalah analisis morfometrik dan indeks kondisi kerang. Hasil penelitian menujukkan bahwa pertumbuhan kerang batik bersifat allometrik negatif dan indeks kondisi kerang dalam keadaan kecil dan sedang.
\end{abstract}

Kata kunci: indeks kondisi, kerang batik, pertumbuhan 


\section{PENDAHULUAN}

Kerang banyak dimanfaatkan sebagai bahan pangan dan cangkangnya digunakan sebagai kerajinan tangan. Perairan Cirebon terdapat di pantai Utara Jawa yang sangat berpotensi dalam menghasilkan jenis-jenis kerang konsumsi. Potensi kekerangan di wilayah Cirebon menjadi pendapatan utama bagi sebagian nelayan. Nelayan lokal biasa menangkap kerang menggunakan garok dan juga menggunakan tangan.

Kerang batik merupakan kerang banyak digemari oleh masyarakat lokal karena dagingnya yang enak. Taksonomi dari kerang batik (Paphia undulate) adalah sebagai berikut: Filum Mollusc, kelas Bivalve, Ordo Veneroida, Genus Paphia, Species Paphia undulate. Spesies ini memiliki cangkang elips yang memanjang. Warnanya coklat kehijauan dengan hiasan pola zigzag coklat tua. Cangkangnya agak tebal dan berwarna kuning kecoklatan. Permukaan cangkangnya halus dan berkilau. Semakin meningkatnya aktivitas penangkapan kerang membuat habitat mulai terganggu. Oleh karena itu perlu dilakukan identifikasi pertumbuhan kerang dan melihat indeks kondisinya.

\section{METODE PENELITIAN}

Penelitian ini dilakukan pada bulan Februari-April tahun 2020. Metode penelitian yang digunakan adalah deskriptif kuantitatif dengan metode pengambilan sampel menggunakan metode purposive sampling. Lokasi pengambilan kerang dipilih berdasarkan aktivitas penangkapan kerang yaitu di perairan Mundu dan Playangan. Sampel kerang didapat dengan bantuan nelayan setempat. Sampel bivalvia diambil menggunakan alat penangkap bivalvia (garuk kerang). Pengambilan sampel bivalvia dilakukan pengulangan sebanyak tiga kali. Garuk kerang dimasukkan ke dalam air setelah dan ditarik menggunakan perahu dan setelah garuk berisi kerang segera diangkat di atas kapal dan dilakukan pemisahan kerang dengan sampah yang ikut terjaring, kemudian dilakukan pencucian dan dimasukkan ke dalam kantong plastik yang berisi alkohol 96\% sebagai pengawet dan diberi label sebagai penanda. Selanjutnya, sampel kerang dianalisis di laboratorium perikanan Universitas Nahdlatul Ulama Cirebon untuk diidentifikasi dengan menggunakan buku acuan (Poutiers 1998;
Dharma 2005; Dance 1977; Setyobudiandi 2004).

\section{Analisis morfometri}

Analisis data pengukuran panjang cangkang kerang dilakukan dari dorsal ke ventral, lebar cangkang kerang dari anterior sampai posterior, sedangkan pengukuran tebal cangkang dimulai dari bawah dan atas umbo (Poutiers 1998). Pengukuran panjang, lebar, dan tinggi cangkang menggunakan jangka sorong analitik dengan ketelitian 0,01 dan penimbangan berat total dengan menggunakan timbangan digital dengan ketelitian 0,01 gr. Analisis pengukuran panjang berat (Gimin et al. 2004; Wanimbo et al. 2017):

$$
Y=a X^{b} \text { atau } \log Y=\log a+b \log X
$$

\section{Keterangan :}

$Y$ : Berat total kerang (gram)

$X$ : Dimensi cangkang (panjang, tinggi, tebal (milimeter))

$a$ : Konstanta, merupakan titik potong garis persamaan regresi sumbu $\mathrm{Y}$

$b$ : Koefisien regresi (penunduk sudut garis dengan sumbu)

Kriteria hubungan panjang berat (pertumbuhan) kerang (Nursalim et al. 2012) yaitu

a. Jika $\mathrm{b}<3$, pertambahan panjang lebih cepat dari pada pertambahan berat atau disebut dengan alometri negatif

b. Jika $b>3$, pertambahan berat lebih cepat daripada pertambahan panjang atau disebut dengan alometri positif

c. Jika $\mathrm{b}=3$, maka pertambahan panjang dan pertambahan berat seimbang atau isometri

\section{Analisis faktor kondisi}

Indeks kondisi pada kerang dapat mengambarkan siklus pemijahan kerang tersebut. Kerang yang mempunyai indeks kondisi tinggi mengindikasikan bahwa organ reproduksinya sedang berkembang dan siap untuk memijah (Quayle 1988).

Pengukuran indeks kondisi ditentukan berdasarkan nilai hubungan berat jaringan lunak kerang dibagi dengan berat total (jaringan lunak kerang dan cangkang) dan dikali seratus (Davenport dan Chen 1987). Pengukuran berat total dengan membuka cangkang kerang kemudian membuang air dalam jaringan lunak kerang 
dengan cara ditiriskan di atas tisu, bersihkan juga jaringan lunak kerang dari lumpur serta makanan yang menempel, setelah itu baru ditimbang berat menggunakan timbangan

Indeks Kondisi $=\frac{\text { Berat Basah Jaringan Lunak Kerang }(g r)}{\text { Berat Total Kerang }(g r)} \times 100$

Adapun pembagian kategori nilai indeks kondisi (Davenport dan chen 1987; Nursalim et al. 2012) adalah sebagai berikut: 1. Nilai indeks kondisi kurang dari 40 adalah kategori kurus.

2. Nilai indeks kondisi antara 40-60 adalah kategori sedang.

3. Nilai indeks kondisi lebih dari 60 adalah kategori gemuk.

\section{HASIL DAN PEMBAHASAN}

Cirebon terletak di Provinsi Jawa Barat pada koordinat 6 62 '30" - 6 $50^{\prime}$ LS dan 108 $30^{\prime}$ - $108^{\circ} 50^{\prime} \mathrm{BT}$, di bagian utara berbatasan dengan Kabupaten Indramayu dan di bagian timur berbatasan dengan Kabupaten Brebes, Provinsi Jawa Tengah. Wilayah ini sangat dipengaruhi oleh Angin Kumbang yang bersifat kering, bertiup kencang, dan terkadang berputar. Curah hujan tertinggi di kawasan perbukitan dan dataran tinggi di bagian selatan Kota Cirebon dan terendah berada di kawasan pesisir dan daratan utara Kota Cirebon (Astjario dan harkins 2005).
Lokasi pengambilan kerang batik di stasiun I (perairan mundu), stasiun II (perairan playangan, dan stasiun III (perairan Bondet). Pada saat penelitian tidak ditemukan kerang batik pada stasiun III hanya ditemukan kerang batik pada stasiun I dan II. Total kerang batik yang diperoleh adalah 62,34 ekor. Keberadaan kerang dapat dilihat pada Tabel 1. Gambar kerang batik dapat dilihat pada Gambar 1.

Kerang batik diperairan Cirebon ditemukan pada dasar perairan lumpur berpasir. kerang batik banyak dimanfaatkan oleh masyarakat setempat untuk dikonsumsi dan dijual untuk memenuhi kebutuhan ekonomi keluarga. Semua jenis bivalvia yang dikonsumsi masyarakat merupakan bivalvia yang tergolong filter feeder. Bivalvia filter feeder mempunyai ciri anatomis berupa insang yang lebih besar dari palp labial karena berkaitan dengan aktivitasnya memompa air (Compton et al. 2007).

Pertumbuhan kerang batik bersifat allometrik negatif yang mana pertumbuhan berat lebih besar dari pada pertumbuhan panjang cangkang. Hal ini dikarenakan kerang lebih mengutamakan lebar cangkang dari pada panjang cangkang. Pada grafik pertumbuhan berat-lebar menunjukkan bahwa kerang batik memiliki nilai allometrik positif $>3$ yaitu pertumbuhan lebar cangkang sebanding dengan pertumbuhan berat cangkang. Interpretasi koefisien korelasi nilai $\mathrm{r}$ dapat dilihat pada Tabel 2.

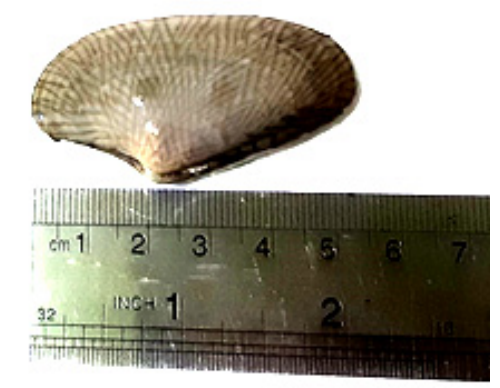

Gambar 1. Kerang batik (Paphia undulate)

Tabel 1. Keberadaan kerang di perairan Cirebon

\begin{tabular}{ccc|cccc}
\hline No. & Spesies & Rep. & $\begin{array}{c}\text { S } \\
\text { (Mundu) }\end{array}$ & $\begin{array}{c}\text { II } \\
\text { (Pelayangan) }\end{array}$ & $\begin{array}{c}\text { III } \\
\text { (Bondet) }\end{array}$ & Total \\
\hline 1 & Paphia undulata & 1 & + & - & - & 6 \\
& 2 & + & + & - & 99 \\
& 3 & + & + & - & 82 \\
\hline
\end{tabular}


Tabel 2. Interpretasi koefisien korelasi nilai $r$

\begin{tabular}{ccc}
\hline Interval & Koefisien & Tingkat Hubungan \\
\hline 0,80 & 1,00 & Sangat kuat \\
0,60 & 0,799 & Kuat \\
0,40 & 0,599 & Cukup kuat \\
0,20 & 0,399 & Rendah \\
0,00 & 0,199 & Sangat rendah \\
\hline
\end{tabular}

Sumber: Analisis data (Syafrizal 2010)

\section{Analisis morfometrik}

Korelasi parameter morfometri panjang cangkang dan berat kerang batik di perairan mundu pada bulan Februari nilai korelasi $\mathrm{R} 2=0,908$ dan nilai $\mathrm{Y}=0,569$, pada bulan Maret nilai korelasi R2 $=0,518$ dan nilai $\mathrm{Y}=0,204$, dan pada bulan April nilai korelasi $\mathrm{R} 2=0,67$ dan nilai $\mathrm{Y}=0,356$ (Gambar 2).

Korelasi parameter morfometri panjang cangkang dan berat kerang batik di perairan playangan pada bulan Maret nilai korelasi $\mathrm{R} 2=0,043$ dengan nilai $\mathrm{Y}=0,368$ dan pada bulan April nilai korelasinya $\mathrm{R} 2=$ 0,091 dengan nilai $Y=0,87$ (Gambar 3).

Kerang batik di stasiun I memiliki korelasi panjang berat dengan hubungan cukup kuat sampai dengan kuat, sedangkan pada stasiun II memiliki nilai hubungan yang rendah dan sangat kuat. Berdasarkan pengalaman nelayan (hasil wawancara) kerang batik banyak didapatkan pada puncak musim penghujan yaitu pada bulan Januari-Februari. Nelayan pada stasiun II menangkap kerang dengan menggunakan alat tangkap garok yang ditarik di kapal sedangkan di stasiiun I nelayan menangkap menggunakan tangan. Kerang pada stasiun II pada bulan Februari tidak ditemukan.
Hal ini dikarenakan penangkapan berlebih, nelayan playangan pada musim puncak bisanya mendapakan kerang sekitar 80-100 $\mathrm{kg} /$ perahu dan pada musim sedang sekitar $50 \mathrm{~kg} /$ perahu. Harga kerang batik yang dijual dari nelayan ke pengepul ikan adalah Rp 8.000-10.000/kg. Karena harga yang cukup tinggi sehingga banyak nelayan yang mencarinya.

Pada musim hujan banyak sumber nutrien dari aktivitas antropogenik mengalir ke laut, sehingga banyak kerang bermunculan. Kerang batik hidup diperairan pesisir yang dekat dengan aliran sungai dan memiliki substrat lumpur berpasir.

Hasil pengamatan menunjukkan bahwa pertumbuhan kerang kepah di Cirebon bersifat allometrik negatif yang mana pertumbuhan cangkang lebih diutamakan, karena ini merupakan strategi kerang untuk mempersiapkan proses reproduksi. Luas volume dari pertumbuhan cangkang akan dapat melindungi jaringan lunak kerang yang terbentuk pada proses berikutnya (Nursalim et al. 2012). Selanjutnya, dikatakan bahwa daya dukung lingkungan seperti ketersediaan makanan, kondisi ekologis, penangkapan, dan musim pemijahan juga mempengaruhi pertumbuhan kerang.

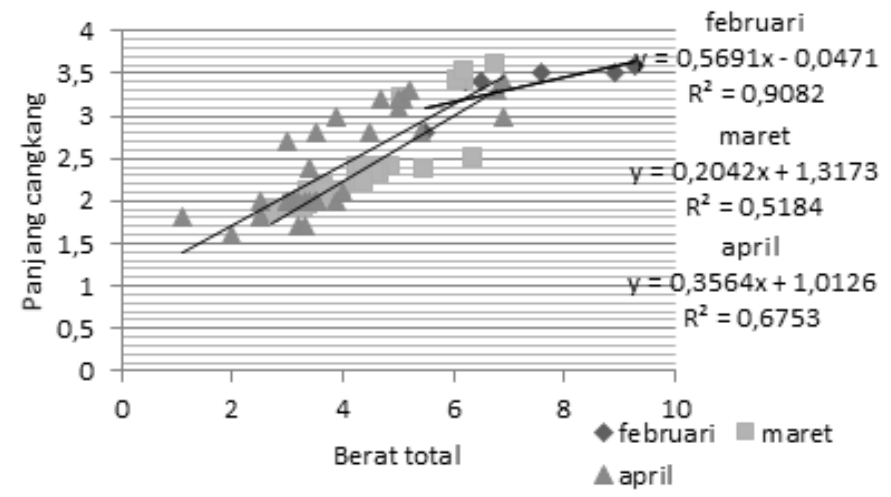

Gambar 2. Pertumbuhan kerang batik di perairan Mundu 


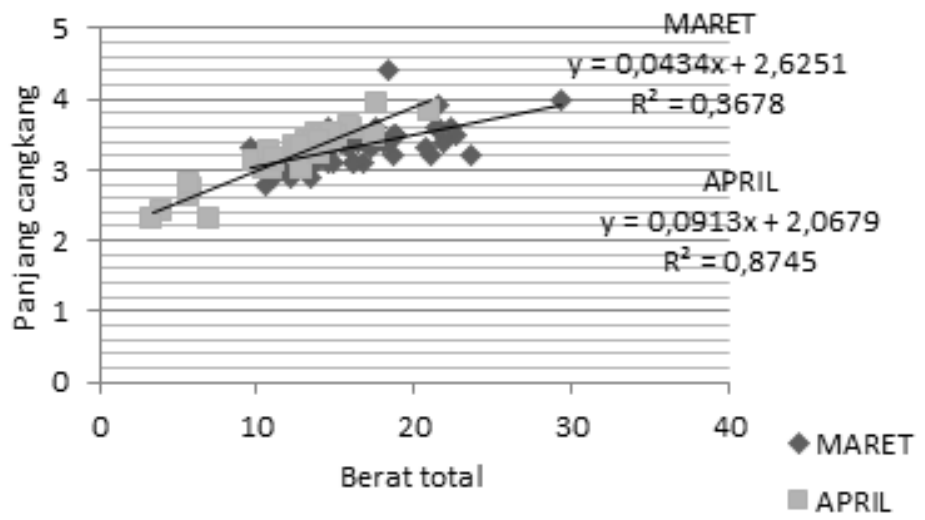

Gambar 3. Pertumbuhan kerang batik di perairan Playangan

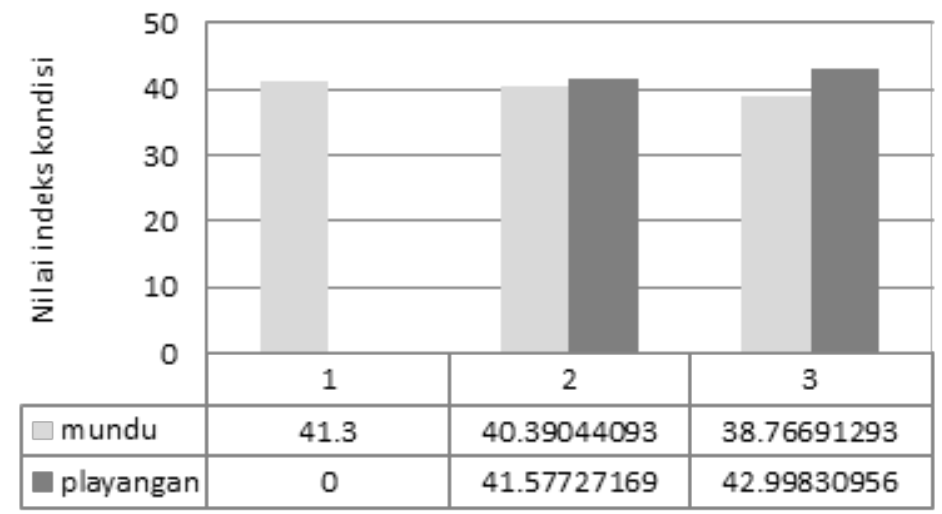

Gambar 4. Indeks kondisi kerang di perairan Cirebon

\section{Indeks kondisi}

Indeks kondisi kerang di perairan Cirebon menunjukkan bahwa kerang di perairan Cirebon dalam kondisi kurus dan sedang. Pada bulan februari di stasiun playangan tidak ditemukan kerang sehingga tidak dapat menghitung indeks kondisi kerang. Nilai indeks kondisi kerang di stasiun mundu berturut-turut adalah 41,3, 40,39, dan 38,76. Nilai indeks kondisi kerang di stasiun playangan berturut-turut adalah 41,58 dan 42,99 (Gambar 4). Nilai indeks kondisi di stasiun mundu cendurung menurun tiap bulannya. Hal ini diduga telah terjadi pelepasan gonad atau kerang dalam keadaan sudah memijah sehingga berat badan kerang berkurang. Indeks kondisi kerang tinggi pada kerang berukuran kecil, diduga kerang ukuran kecil sedang terjadi proses reproduksi. Nilai indeks kondisi yang besar menandakan bahwa kerang sedang melakukan siklus reproduksi atau sedang mengalami matang gonad (Nursalim et al. 2012). Selanjutnya, pada ukuran kerang sedang diduga kerang telah melakukan proses pemijahan atau pelepasan gonad, sehingga nilai indeks kondisnya menurun.

\section{KESIMPULAN DAN SARAN}

\section{Kesimpulan}

Pertumbuhan kerang batik bersifat allometrik negatif yang mana pertumbuhan berat lebih besar dari pada pertumbuhan panjang cangkang. Indeks kondisi kerang menunjukkan kerang dalam keadaan kurus dan sedang.

\section{Saran}

Penelitian ini diharapakan bisa menjadi masukan bagi pemerintah dalam mengelola dan memanfaatkan kawasan pesisir

\section{UCAPAN TERIMAKASIH}

Terima kasih kepada Direktorat Pendidikan tinggi BRIN yang telah memberikan biaya penelitian lewat skema penelitian dosen pemula tahun anggaran 2020. 


\section{DAFTAR PUSTAKA}

Astjario P, Harkins FX. 2005. Penelitian Lingkungan Pantai Wilayah Pesisir Kabupaten Cirebon, Jawa Barat. Jurnal Geologi Kelautan. 3(2): 19-26.

Compton TJ, Drent J, Kentie R, Pearson GB, van deer Meer J, Piersma T. 2007. Overlap in the Feeding Morphology of Bivalves from Spesies-Richand Spesies-Poor Intertidal Flats Using Gill-Palp Ratios for Comparative Analyses of Mollusc Assemblages. Mar Ecol Prog Ser. 348: 213-220.

Dance SP. 1977. The Encyclopedia of Shells London Blanford Press. 288.

Davenport J, Chen X. 1987. A Comparison of Methods for The Assessment of Condition in The Mussel (Mytillus edulis L.). Journal Mollusca Studie. 53: 293-297.

Dharma B. 2005. Recent and Fossil Indonesian Shells. Germany Conch Books.

Gimin R, Mohan R, Thinh LV, Griffiths AD. 2004. The Relationship of Dimension and Shell Volume to Live Weight and Soft Tissue Weight in the Mangrove Clam, Polymesoda erosa (Solander, 1786) from Notherm Australia Artivles Naga. Worldfish Centre Quarterly. 27 (3 \& 4): 32- 35.

Nursalim HR, Suprijanto J, dan Widowati

I. 2012. Studi Bioekologi Kerang
Simping (Amusium pleuronectes) di Perairan Semarang dan Kendal. Journal of Marine Research. 1(1): 110-117.

Poutiers JM. 1998. Bivalves Acephala, Lamellibranchia, Pelecypoda. In: Carpenter KE and Niem VH. 1998. FAO Species Identification Guide for Fishery Purposes. The Living Marine Resources of The Western Central Pacific. Seaweeds, Corals, Bivalves, and Gastropods. Rome, FAO. 1: 123362.

Quayle DB. 1988. Tropical Oyster Culture and Methods. International Development Research Center. Ottawa, Canada. 79p.

Setyobudiandi I, Soekendarsih E, Vitnerdan Y, Setiawati R. 2004. Bio-ecologi of Lamis Clam (Meretrix meretrix) in Marunda Waters. Journal of Water Sciences and Fisheries Indonesia. 11(1): 61-66.

Wanimbo E, Sutrisno A, Ita W. 2017. Pola Pertumbuhan, Respon Osmotik dan Tingkat Kematangan Gonad Kerang Polymesoda erosa di Perairan Teluk Youtefa Jayapura Papua. Prosiding Aplikasi IPTEK Perikanan dan Kelautan dalam Pengelolaan Mitigasi Bencana dan Degradasi Wilayah Pesisir, Laut, dan Pulau-Pulau kecil. UNDIP Semarang. 